\title{
Effects of Preparation's Parameters on Stabilization of Sabodala Gold Mine Tailings: Comparison of Fresh and Weathered Materials
}

\author{
Ibrahima Dia1, CheikhIbrahima Faye1, Dame Keinde², Mababa Diagne1, Mamadou Gueye1 \\ ${ }^{1}$ Institut des Sciences de la Terre, Université Cheikh Anta Diop de Dakar, Dakar Fann, Senegal \\ ${ }^{2}$ Ecole Supérieure Polytechnique, Université Cheikh Anta Diop de Dakar, Dakar Fann, Senegal \\ Email: ibrahima4.dia@ucad.edu.sn
}

How to cite this paper: Dia, I., Faye, C., Keinde, D., Diagne, M. and Gueye, M. (2017) Effects of Preparation's Parameters on Stabilization of Sabodala Gold Mine Tailings: Comparison of Fresh and Weathered Materials. Journal of Geoscience and Environment Protection, 5, 21-35.

https://doi.org/10.4236/gep.2017.59003

Received: July 26, 2017

Accepted: August 20, 2017

Published: August 23, 2017

Copyright $\odot 2017$ by authors and Scientific Research Publishing Inc. This work is licensed under the Creative Commons Attribution International License (CC BY 4.0).

http://creativecommons.org/licenses/by/4.0/

(c) $\underset{\mathrm{EY}}{\text { (i) Open Access }}$

\begin{abstract}
The Sabodala gold mine tailings were stabilised using geopolymerization technics in order to improve their mechanical properties in general for a reuse as building materials for local communities. The effect of several preparation parameters on the compressive and tensile strength of the stabilised tailings has been studied to define their optimums. For each formulation, all parameters are kept constant and only one is variable. The prepared samples are then tested for compressive and tensile strength to see how the variable parameter impact on these properties. The same work was carried out for the fresh tailings and for the weathered one to see whether they behave differently and if they need different treatment. The results show that for most of parameters, there is an optimal value on either side of which compressive and tensile strength decrease. Except for few parameters, the fresh and the weathered tailings have a similar behaviour with regards to trends of their mechanical properties with changing preparation conditions. In addition to the similarity of weathered and fresh tailings mechanical characteristics following their stabilization by geopolymerization, this work has proved the considerable effects of the preparation's parameters.
\end{abstract}

\section{Keywords}

Gold Tailings, Geopolymerization, Stabilization, Compressive Strength, Tensile Strength

\section{Introduction}

For gold mines like Sabodala, few grams of gold are recovered for each ton of processed ore leaving most of it as valueless residue. The costs related to disposal 
of the large amount of residue are considerable and the facilities hosting it are to be rehabilitated before the closure of the mine increasing the expenses of the mine operator.

As part of his environmental protection policy, Sabodala Gold Operations (SGO) has initiated a study on the reuse of the tailings to first preclude any potential damage to the environment but also to make local communities benefit from value created from this reuse.

This work aims by applying geopolymerization technics, to study the effects of material preparation's parameter in order to find the optimal formulation for tailings stabilization. This will help define the best way of enhancing the geotechnical properties of the tailings for reuse as building material at lowest stabilization cost.

The geopolymer defines an alkali-activated alumino-silicate material through chemical reaction between the alumino-silicate complexes and the alkali metal under strong alkaline conditions [1]. The geopolymerization reaction leads to the formation of a stable material (the geopolymer) characterized by amorphous polymeric structure with solid interconnected Si-O-Al-O-Si bonds [2]. The silica and alumina content of the Sabodala mine tailings are high enough to justify the study of their stabilization by geopolymerization. The geopolymerization reactions are proven to be effective on natural clays with silica and alumina content's range similar to Sabodala tailings one [3]. Diop et al. [3] had, in a previous report, pointed out the influence of curing temperature, alkaline solution concentration and drying method.

This paper, in addition to the geopolymerization process, aims also to test the contribution of addition of conventional Portland cement and limes to the mechanical properties of the stabilised tailings.

By late 2015, the Tailings Storage Facility was filled with more than 16 million tons of low moisture content tailings. This low cost raw material is an extraordinary opportunity for local communities if it can be stabilised with efficient process like geopolymerization.

\subsection{Site Description}

Sabodala mine is located in the Kedougou region of south eastern Senegal; approximately $850 \mathrm{~km}$ east of the capital Dakar.

The local climate is of soudano-guinean, or tropical Savannah, in accordance with the Koppen classification [4] with a local average insolation of 2950 hours per annum and average temperatures ranging from $22.8^{\circ} \mathrm{C}$ to $34.8^{\circ} \mathrm{C}$. The rainy season runs from May to October with an average of $1248 \mathrm{~mm}$ of rain per annummainly falling within the rainy season [5].

The Sabodala gold mine is situated within the West African Birimian greenstone geological gold belt in a region of orogenic shearing. The deposit belongs to the Senegal-Mali border basement named Kedougou Keniaba inlier (KKI) which is the west most part of the West African Craton. 
Regional mapping indicates that the Senegalese portion of the KKI contains two units (a volcanic belt and a metasedimentary basin) separated by a major shear zone named Main Transcurrent Zone [6].

The Sabodala deposit is hosted by the sequence of mafic volcanic and volcaniclastic rocks, gabbro, cherty to siliciclastic sediments, and structurally late felsic dykes [7]. All these lithologies may host the gold mineralisation but the most extensive mineralised area are localised in the volcaniclastic rocks and cherty sediments for the fresh part [8]. For the oxidised part, in addition to these facies, more ultramafic mineralised rocks are noted.

The mineralogy can be described as dominated by the following species: ferromagnesian species likes Fe/Mg rich pyroxenes and their alteration products, plagioclase, chlorite, talc and accessory serpentine, silica varieties.

The Sabodala deposit is characterized by multiple gold mineralization styles which all are associated with pyrite being hosted by quartz shear and quartzcarbonate extensional veins, disseminated in broad zones of carbonate-albite alteration surrounding shear veins or disseminated in hydraulic breccia with quartz-carbonate-albite matrix [8]. The Masato satellite is of similar style than Sabodala from a geological point of view. However the Sabodala is mainly fresh and from surface whereas Masato has a normal profile with weathered material at top.

\subsection{Sabodala's Tailings Storage Facility (TSF)}

The tailings storage facility at Sabodala gold mine covers an approximate surface of 274 ha and is located in a valley which is closed by engineered embankments. Tailings are discharged in the form of slurries by spigots installed at regular distances on a pipe by which these slurries are pumped from the process plant. The spigots are switched on and off alternatively to enable a proper drying of the tailings and the water to decant at the centre of the TSF. Figure 1 shows the location, in the TSF, of the three pits dug to collect bulk samples used for this study.

Tailings from two different ore types are being discharged at the Sabodala TSF: the fresh one produced from the processing of fresh ore coming from Sabodala pit and the weathered one produced from the blended ore. The blended ore is a mixture of ores coming from the two pits (Sabodala and Masato).

\section{Materials and Methodology}

\subsection{Sampling Procedure}

Based on the work performed previously on auger drill holes, three locations were selected to undertake pitting in order to collect enough bulk samples to run this study. Due to the active deposition of tailings, the locations were limited to beach areas where the tailings were firm enough to safely take the weight of the sampling personnel. For the need of the sampling, shovels were used to dig the 
pits and collect the fresh and oxidised materials which were first separated and vigorously homogenised before being placed in plastic bags and then in polywave bags. Figure 2 illustrates one sampling pit which shows the fresh tailings from Sabodala pit surmounted by weathered tailings from blended ore (Sabodala and Massato).

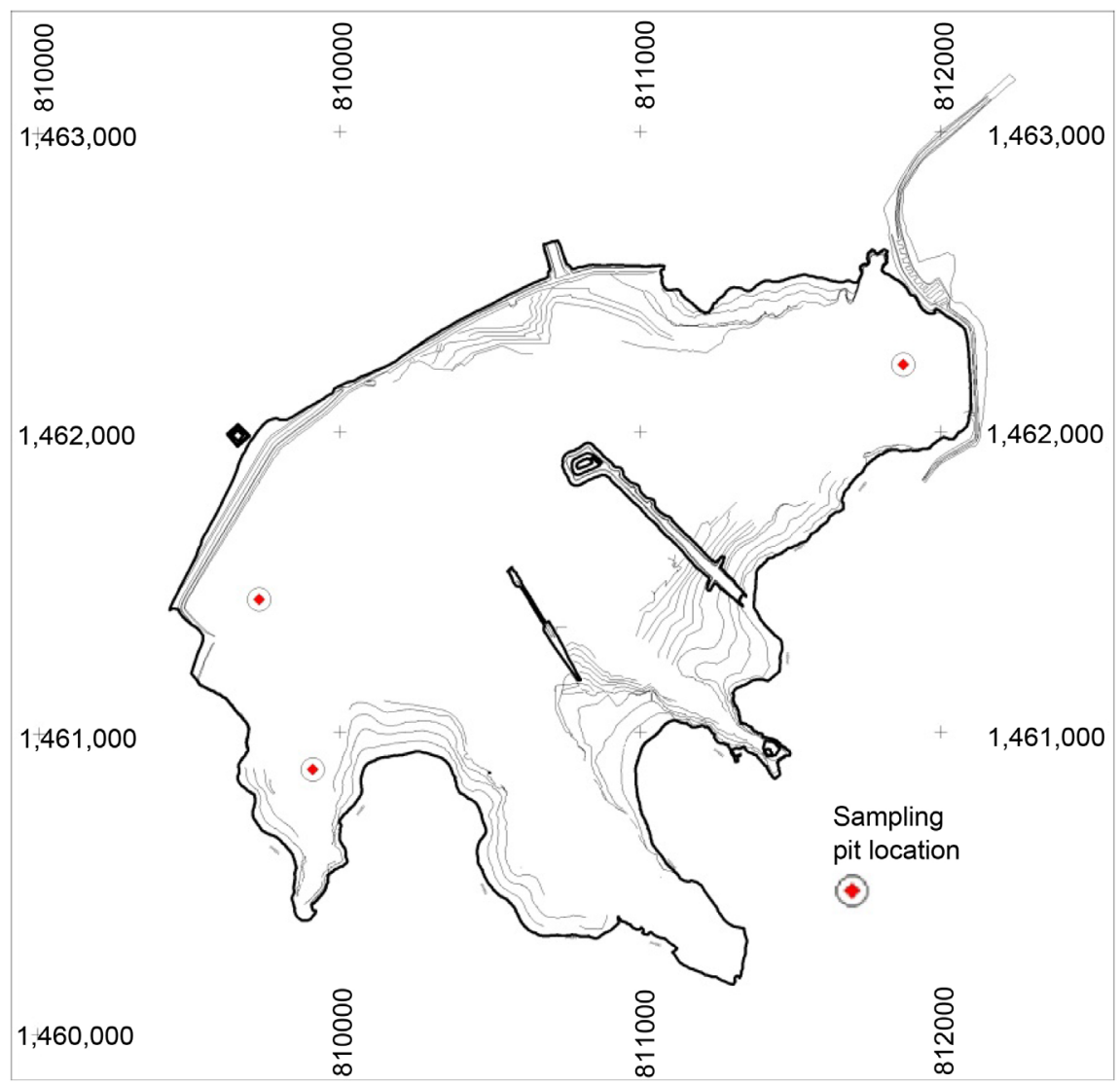

Figure 1. Pits location onto sabadola's tailings storage facility layout.

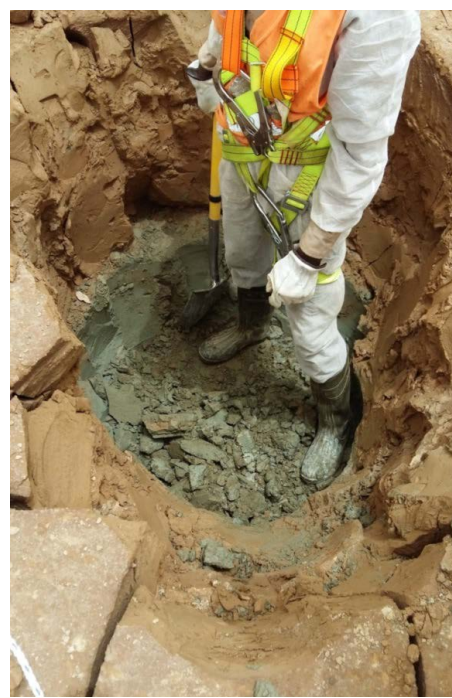

Figure 2. Ongoing digging of a sampling pit. 


\subsection{Sample Preparation}

Two composite samples (weathered on one hand and fresh material on the other hand) from all pits were dispatched to the ISO 17025 accredited ALS laboratory in Johannesburg for sample preparation and analysis. These samples, labelled$\mathrm{C} 001, \mathrm{C} 002$, were dried at $105^{\circ} \mathrm{C}$ for 24 hours prior to disaggregation. The following physical and chemical tests were undertaken: particle size distribution analysis, whole rock multi element assay following strong acid digestion, bulk mineralogy by fine powder X-Ray Diffraction (XRD) with Rietveld refinement.

Particle size distribution analyses were performed according to French standards NF P 94-056 [9] and NF P 94-057 [10] respectively by dry sieving and hydrometer method (for 80 microns passes).

The weathered and fresh tailings are then treated separately by using geopolymerization method to enhance their geotechnical properties in order to be used as building materials.

\subsection{Ray Diffraction Analysis}

All the samples were analysed using X-ray diffraction (XRD) technique and they were prepared using a back-loading preparation method. The samples were analysed with a PANalytical Empyrean diffractometer with PIXcel detector and fixed slits with $\mathrm{Fe}$ filtered $\mathrm{Co}-\mathrm{K} \alpha$ radiation. The phases were identified using X'Pert Highscore plus software. The relative phase amounts were estimated using the Rietveld method. This technique is unable to identify amorphous or poorly crystalline material [11].

\subsection{Whole Rock Analysis}

These tests were conducted by a commercial laboratory using Inductively Coupled Plasma (ICP) method. The major elements ( $\mathrm{Si}, \mathrm{Al}, \mathrm{Fe}, \mathrm{Ca}, \mathrm{Mg}, \mathrm{Na}, \mathrm{K}, \mathrm{Cr}$, $\mathrm{Ti}, \mathrm{Mn}, \mathrm{P}, \mathrm{Sr}$, and $\mathrm{Ba}$ ) are analysed using ICP-AES (Atomic Emission Spectroscopy)method with lithium borate and lithium tetra-borate flux being mixed with the sample to lower the fusion point of the mixture which is then fused in a furnace. The produced melt is dissolved in nitric and chlorohydrin acids. Carbon was analysed using the Leco furnace equipment.

\subsection{Samples Preparation Procedure for Tailings Stabilization}

The aim of the stabilization of the tailings is to improve their geotechnical properties so that they can be used as building material.

This stabilization is performed by mixing the tailings with an alkaline solution and, in some cases, adding limes or cement. The product is then cured at different temperatures after a variable drying period. The following products were used to form the mix: the tailings, a sodium hydroxide solution (the alkaline solution) at different concentrations, Portland cement with a compressive strength of $42.5 \mathrm{MPa}$ at 28 days and hydrated limes $\left(\mathrm{Ca}(\mathrm{OH})_{2}\right)$.

The sample preparations were performed using dedicated equipment among 
which: an electronic scale, a mortar mixer (Controlab L0031.6), $4 \times 4 \times 16 \mathrm{~mm}$ steel moulds (Controlab E0107), a standard jolting apparatus for compaction by percussion (Controlab E0130) and an oven.

After having been filled with the mix, the steel moulds are placed on the jolting apparatus and compaction runs for three minutes. The $4 \times 4 \times 16 \mathrm{~mm}$ briquettes are extracted from the moulds for drying. The dried briquette are then placed into the oven and cured at different temperatures.

For each preparation, all parameters are maintained constant except the studied one which is variable.

\subsection{Compressive and Tensile Strength Measurements}

The mechanical performances of the stabilised tailings were measured using an unconfined compression and flexion testing machine (Controlab E0160S). For each preparation, a set of three briquettes are tested and average compressive and tensile strengths are calculated from it.

\section{Results}

\subsection{Particle Size Distribution}

Sabodala's tailings are generally very fine and according to the European standard [12], they belong to the fine sandy loam particle size fraction. Figure 3 shows the results of particle size distribution analysis. It is to be noted that irregularities observed at 80 microns diameter is most likely related to the change of analysis method (dry sieving to hydrometer method).

\subsection{Mineralogical Composition}

Mineralogical analysis results are shown in Table 1 and show the predominance of quartz and plagioclase in both oxidised and freshtailings. These two mineral phases content are oppositely higher in the oxidised (quartz) and fresh (plagioclase) tailings. The oxidised sample shows higher concentrations of secondary weathering minerals: kaolinite, goethite and talc.

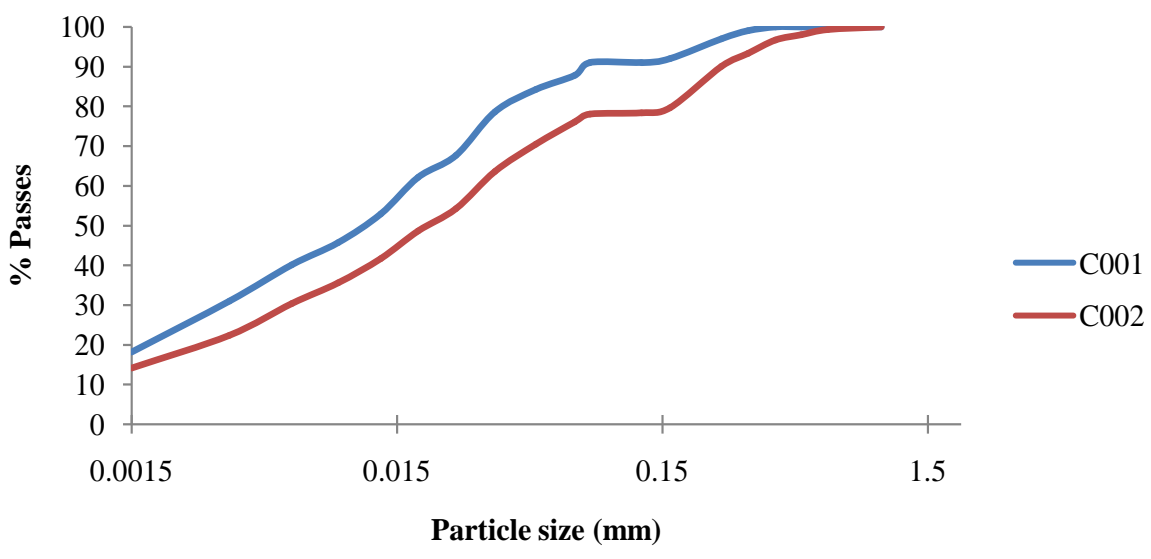

Figure 3. Particle size distribution of the Sabodala tailings. 
Table 1. Quantitative mineralogical composition through XRD analysis (result in \% by weight).

\begin{tabular}{cccc}
\hline Minerals & Chemical formulae & $\mathrm{C001}$ & $\mathrm{C002}$ \\
\hline Quartz & $\mathrm{SiO}_{2}$ & 44.86 & 31.32 \\
Plagioclase (mainly albite) & $(\mathrm{Na}, \mathrm{Ca})\left(\mathrm{Si}, \mathrm{Al}_{4} \mathrm{O}_{8}\right.$ & 11.74 & 22.51 \\
Dolomite & $\mathrm{CaMg}\left(\mathrm{CO}_{3}\right)_{2}$ & 3.70 & 15.55 \\
Chlorite & $(\mathrm{Mg}, \mathrm{Fe})_{5}\left(\mathrm{Si}_{2}, \mathrm{Al}_{4} \mathrm{O}_{10}(\mathrm{OH})_{8}\right.$ & 6.34 & 7.14 \\
Muscovite & $\mathrm{KAl}_{2}\left(\mathrm{AlSi}_{3} \mathrm{O}_{10}\right)(\mathrm{F}, \mathrm{OH})_{2}$ & 10.93 & 8.96 \\
Talc & $\mathrm{Mg}_{3} \mathrm{Si}_{4} \mathrm{O}_{10}(\mathrm{OH})_{2}$ & 4.04 & 3.25 \\
Kaolinite & $\mathrm{Al}_{2} \mathrm{Si}_{2} \mathrm{O}_{5}(\mathrm{OH})_{4}$ & 9.25 & 2.95 \\
Siderite & $\mathrm{FeCO}_{3}$ & 0.05 & 3.21 \\
Chalcopyrite & $\mathrm{CuFeS}_{2}$ & 0.74 & 1.47 \\
Pyrite & $\mathrm{FeS}_{2}$ & 0.46 & 1.54 \\
Pyrrhotite & $\mathrm{FeS}_{22}$ & 0.22 & 0.24 \\
Actinolite & $\mathrm{Ca}_{2}(\mathrm{Mg}, \mathrm{Fe})_{5} \mathrm{Si}_{8} \mathrm{O}_{22}(\mathrm{OH})_{2}$ & 0.00 & 1.75 \\
Goethite & $\mathrm{FeO}(\mathrm{OH})$ & 7.67 & 0.13 \\
\hline
\end{tabular}

Carbonate minerals are mainly represented by dolomite accompanied with minor siderite. In general, carbonate minerals are more abundant in the fresh than in the oxidised tailings indicating that they have been partially consumed due to oxidation of sulphides and dissolution by rainwater.

Sulphide minerals are mostly represented by pyrite and chalcopyrite and to a lesser extent by pyrrhotite with a total sulphides average content of $1.4 \%$ in oxidised tailings and $3.3 \%$ in fresh tailings. The remaining mineral species occurring are mainly silicates.

\subsection{Near Total Solid Phase Elemental Concentrations}

The near total solid phase elemental analysis results are shown in Table 2. In general terms, the fresh tailings are richer in carbon, calcium, magnesium, sodium and sulphur. Contrariwise, compared to weathered one, they are depleted in potassium, chromium, nickel. In both materials, silica and aluminium are considerably more dominant.

\subsection{Effect of the Preparation Parameters on the Strength of the Stabilised Tailings}

In order to stabilise the Sabodala tailings for improved mechanical performances and at a lowest cost, it is compulsory to optimise the preparation parameters like the alkaline solution concentration, the percentage by mass of cement and alkaline solution etc. Where relevant, the standard error for tensile and compressive strength is indicated on the diagrams below (above the points for fresh tailings and below for weathered tailings).

1) Effect of the sodium hydroxide concentrations

This set of samples was prepared with $3 \%$ of cement, $18 \%$ and $21 \%$ of alkaline 
Table 2. Near total solid phase elemental composition.

\begin{tabular}{cccc}
\hline Element & Unit & C001 & C002 \\
\hline $\mathrm{Al}$ & $\%$ & 6.31 & 5.34 \\
$\mathrm{Ba}$ & $\%$ & 0.02 & 0.02 \\
$\mathrm{C}$ & $\mathrm{ppm}$ & 9400 & 26166 \\
$\mathrm{Ca}$ & $\%$ & 1.96 & 4.85 \\
$\mathrm{Cr}$ & $\mathrm{ppm}$ & 1440.00 & 290.00 \\
$\mathrm{Cu}$ & $\mathrm{ppm}$ & 124.00 & 88.33 \\
$\mathrm{Fe}$ & $\%$ & 7.65 & 7.06 \\
$\mathrm{~K}$ & $\%$ & 1.50 & 0.91 \\
$\mathrm{Mg}$ & $\%$ & 1.57 & 2.91 \\
$\mathrm{Mn}$ & $\%$ & 0.09 & 0.09 \\
$\mathrm{Na}$ & $\%$ & 0.93 & 1.95 \\
$\mathrm{Ni}$ & $\mathrm{ppm}$ & 481.00 & 140.00 \\
$\mathrm{P}$ & $\%$ & 0.06 & 0.06 \\
$\mathrm{~S}$ & $\mathrm{ppm}$ & 2300 & 10166 \\
$\mathrm{Si}$ & $\%$ & 28.11 & 24.12 \\
$\mathrm{Sr}$ & $\mathrm{ppm}$ & 70.70 & 132.67 \\
$\mathrm{Ti}$ & 0.51 & 0.51 \\
\hline
\end{tabular}

solution respectively for fresh and weathered material. The samples were cured at $210^{\circ} \mathrm{C}$ and mechanical tests run at 7 days.

The results show that compressive and tensile strengths increase with the concentration of the sodium hydroxide solution for both fresh and weathered tailings (Figure 4). This suggests that more concentrated solutions promote better rate of geopolymerization reactions by creating more alkaline conditions.

2) Effect of the percentage by mass of cement

The aim here is to study the effect of increasing cement percentage by mass. This set of samples was prepared with $18 \%$ and $21 \%$ (fresh and weathered tailings) of an 8 molar concentrated alkaline solution and curing temperature of $210^{\circ} \mathrm{C}$. Mechanical tests were done at 7 days.

The optimal concentration by mass of cement is obtained at 3.5\% where the compressive strength reaches $20 \mathrm{MPa}$ for fresh material and $18 \mathrm{MPa}$ for weathered material (Figure 5). The decrease of mechanical performances when the percentage of cement exceeds $3.5 \%$ could be explained by the consumption of part of the solution's water by the cement during its hydration. This reduction of the water causes also the reduction of the percentage by mass of the alkaline solution.

3) Effect of the percentage by mass of sodium hydroxide solution

For this set of samples, the alkaline solution concentration is fixed at 8 molar, the curing temperature at $210^{\circ} \mathrm{C}$ and the percentage of cement at $3 \%$ while the percentage by mass of alkaline solution varies. Mechanical tests were done at 7 days. 


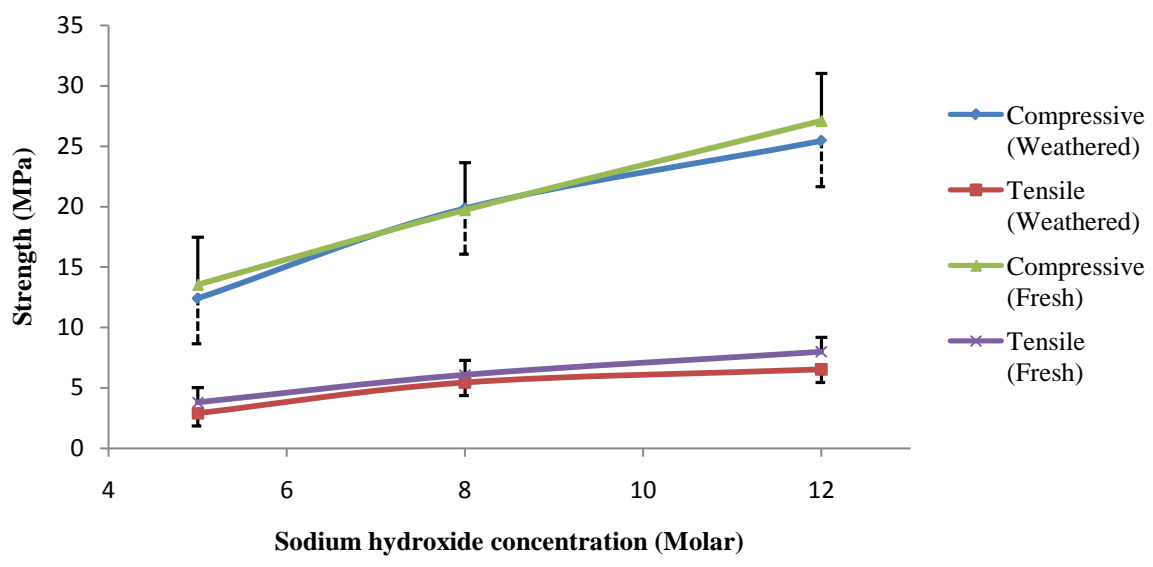

Figure 4. Effect of sodium hydroxide concentration on tailings strength after stabilization.

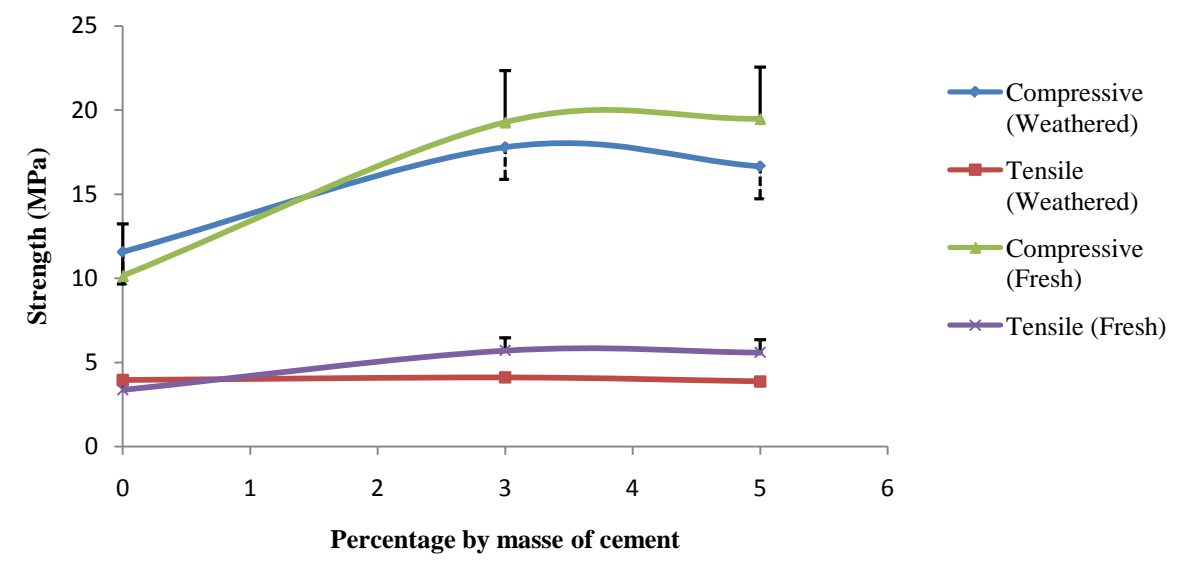

Figure 5. Effect of percentage by mass of cement on tailings strength after stabilization.

The percentage by mass of the alkaline solution is optimal at $18 \%$ for the fresh tailings and $21 \%$ for the weathered one (Figure 6). On this diagram, the decrease of strengths on the left of the optimum is most likely caused by poor contact between the silico-alumina complexes and the alkaline solution due to its insufficiency. Beyond the optimum, the high liquid/solid ratio results in additional porosity which reduces the compactness of the material and then its compressive and tensile strength.

4) Effect of the curing temperature

This set of samples was prepared with $3 \%$ of cement, $18 \%$ and $21 \%$ (fresh and weathered tailings) of 5 and 8 molar concentrated alkaline solutions. Mechanical tests were done at 7 days. Due to non-consistent trends observed with the samples prepared using an 8 molar solution, a second set were prepared, for this parameter, using a 5 molar solution. It is admitted that the curing temperature have a considerable effect on the geopolymer's mechanical performances, their porosity and their microstructures [13].

For an 8 molar concentrated alkaline solution and for tensile strength, the curing temperature is optimal at $110^{\circ} \mathrm{C}$. The tensile strength decreases (up to $210^{\circ} \mathrm{C}$ ) and increases again with increasing curing temperature. This is noted for 


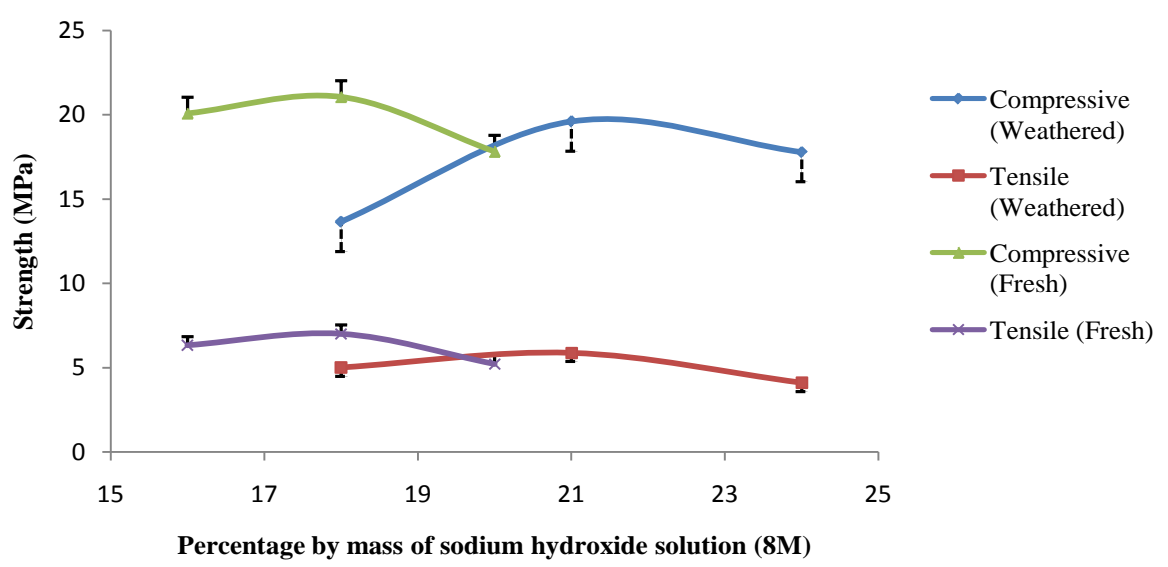

Figure 6. Effect of percentage by mass of $\mathrm{NaOH}$ solution on tailings strength after stabilization.

both fresh and weathered tailings.

Except for compressive strength for fresh material with an 8 molar concentration solution, all other formulations lead to an optimal curing temperature of $210^{\circ} \mathrm{C}$ (Figure 7 and Figure 8). Bakharev [13] stated a reduction of $\mathrm{Si} / \mathrm{Al}$ ratios in the silico-alumina gel (the geopolymer material) with an increasing temperature of heat. This fact could explain in most cases on the graph below the decrease of strength beyond a curing temperature of $210^{\circ} \mathrm{C}$.

5) Effect of the time for different drying method

To study the effect of the time, two second sets of briquettes were prepared for each formulation and tested for compressive strength at 7 and 28 days for two different drying methods: under a shelter and in an oven $\left(110^{\circ} \mathrm{C}\right)$. In both cases, the briquettes are dried for 6 full days and tested the seventh one.

For both weathered and fresh tailings, the briquettes dried under the shelter at room temperature show a maintaining of strengths values between 7 and 28 days. For those dried into the oven, the compressive strength decreases with the time (Figure 9). Bakharev [13] concluded, in previous study done on fly ash, that long drying at room temperature is more beneficial for strength development of geopolymeric material. He also stated the reversibility character of changes observed for samples pre-cured at high temperature for 24 hours using a sodium silicate activator.

6) Effect of the type of additive

This part compares the contribution of the additional binder (cement and limes) on the improvement of mechanical properties of the Sabodala's gold tailings. Samples were prepared with $18 \%$ and $21 \%$ (respectively fresh and weathered) of an 8 molar concentrated solution and a curing temperature of $210^{\circ} \mathrm{C}$.

Cement and limes both act by creating cementitious compounds through pozzolanic reactions [14] [15]. While studying soil stabilization with lime, Jha and Sivapullaiah [14] reported a drastic increase in strength with addition of lime and did explain it by the filling and binding of open fabrics with by the formation of cimentitious compounds. Cement also creates binds between 


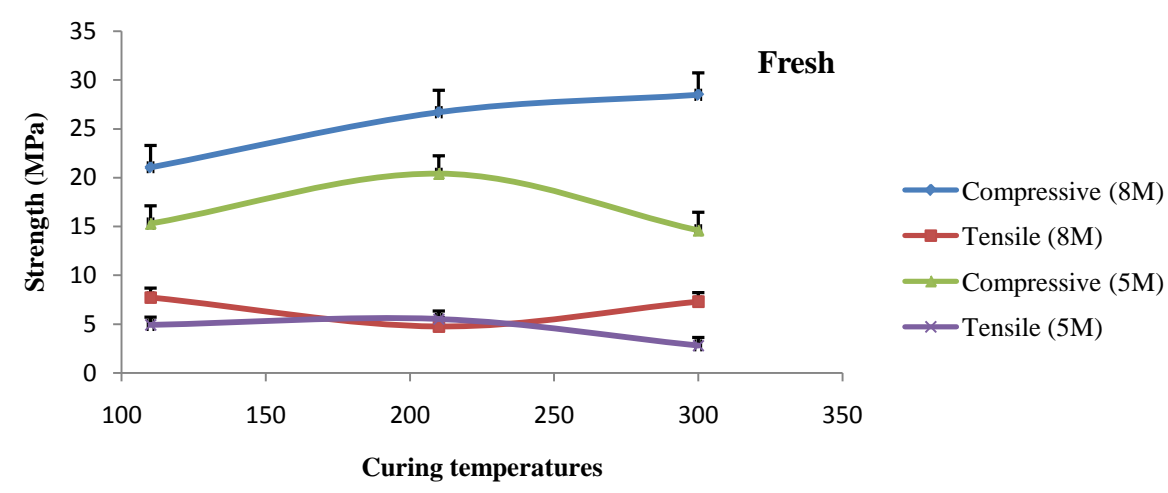

Figure 7. Effect of curing temperatures on fresh tailings strength after stabilization.

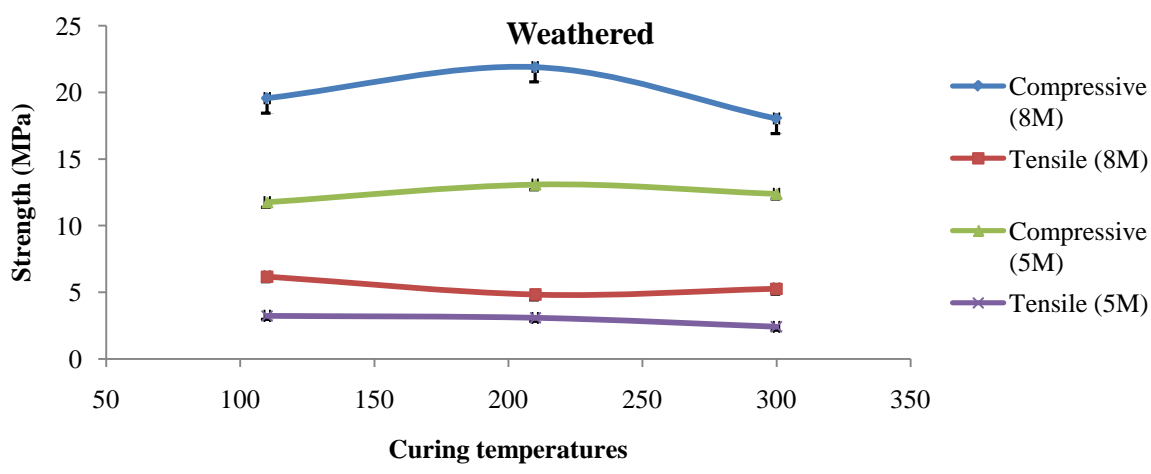

Figure 8. Effect of curing temperatures on weathered tailings strength after stabilization.

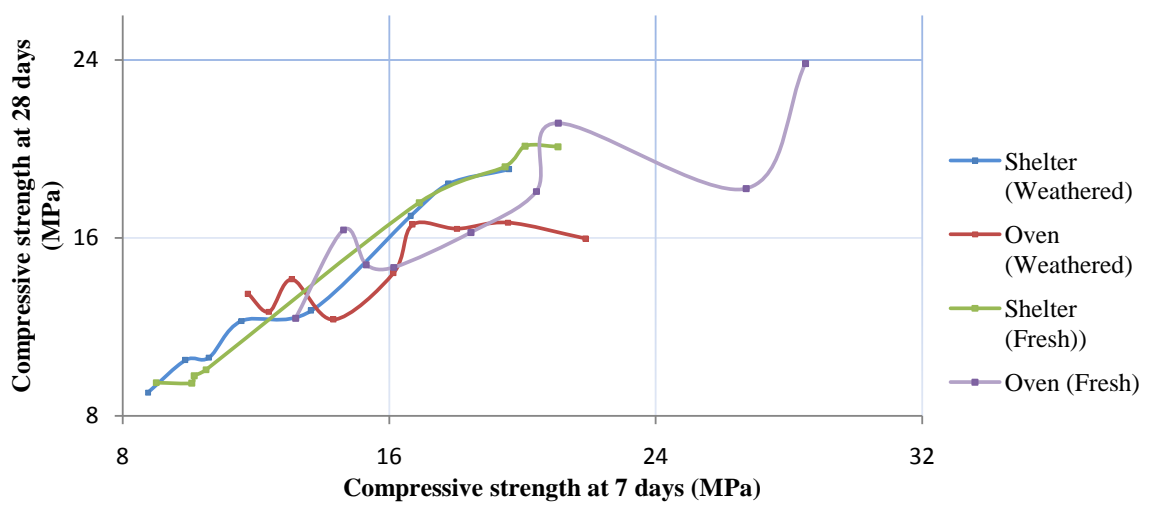

Figure 9. Effect of the time on tailings strength after stabilization.

particles that reduce porosity and increase mechanical performance [15].

The range of strength increase depends heavily on the amount of cementitious compounds formed during the curing of the treated material.

In general, for Sabodala's tailings, the limes offer better results than cement and the mechanical properties of the material is much highly improved by limes (Figure 10). This suggests that, the amount of pozzolanic reaction and cementitious compounds formation is higher with limes than with Portland cement.

7) Effect of the drying method

Samples are prepared with $3 \%$ of cement, $18 \%$ and $21 \%$ of an 8 molar concen- 


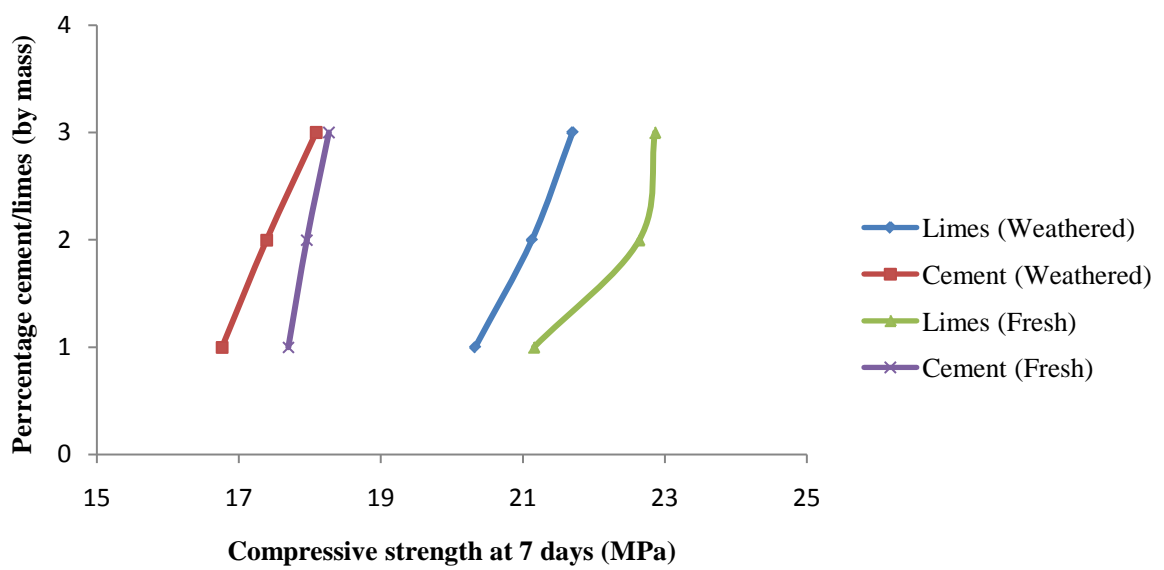

Figure 10. Effect of the additive type on tailings strength after stabilization.

trated alkaline solution and cured at $210^{\circ} \mathrm{C}$. To test the effect of the pre-curing method on the treated material's strengths, half of it is dried under the shelter at room temperature and the other half into the oven at $110^{\circ} \mathrm{C}$ and for 6 full days.

The samples dried under a shelter result in smaller compressive strength than those dried in the oven (Figure 11).

\section{Discussions}

It is proven than alkali activation can considerably improve the mechanical performances of mine tailings [16]. This work has focused on the effects of several preparations' parameters on the stabilization of mine tailings (Sabadola gold mine) by studying how they influence the strengths of the treated material. The studied parameters are the concentration of sodium hydroxide solution, the percentage by mass of cement and sodium hydroxide solution, the curing temperature, the time, the type of additive (cement of limes) and the drying method.

Each parameter is studied individually with changing values and constant values are applied for all other parameters. This protocol doesn't, however, provide any indication on the effects of the studied parameter on different conditions (different values for the other parameters).

Most of parameters (where optimums are relevant)show an optimal value for which compressive and tensile strength are higher. It is the case of the percentage by mass of $\mathrm{NaOH}$ solution and curing temperature (in most cases).

The increase of $\mathrm{NaOH}$ solution concentration leads to a continuous increase of stabilized tailings strength. Due to the high cost of very concentrated $\mathrm{NaOH}$ solutions and the need to consider economic aspects of tailings reuse as building materials, this study did not go beyond 12 molar concentrated solutions.

There are unexplained trends with varying curing temperature for samples prepared with an 8 molar concentrated solution. These trends are not consistent with results from the 5 molar concentrated solutions. In addition, the tensile and compressive strengths (for both fresh and weathered materials) do not show any obvious link for 8 molar solutions. 


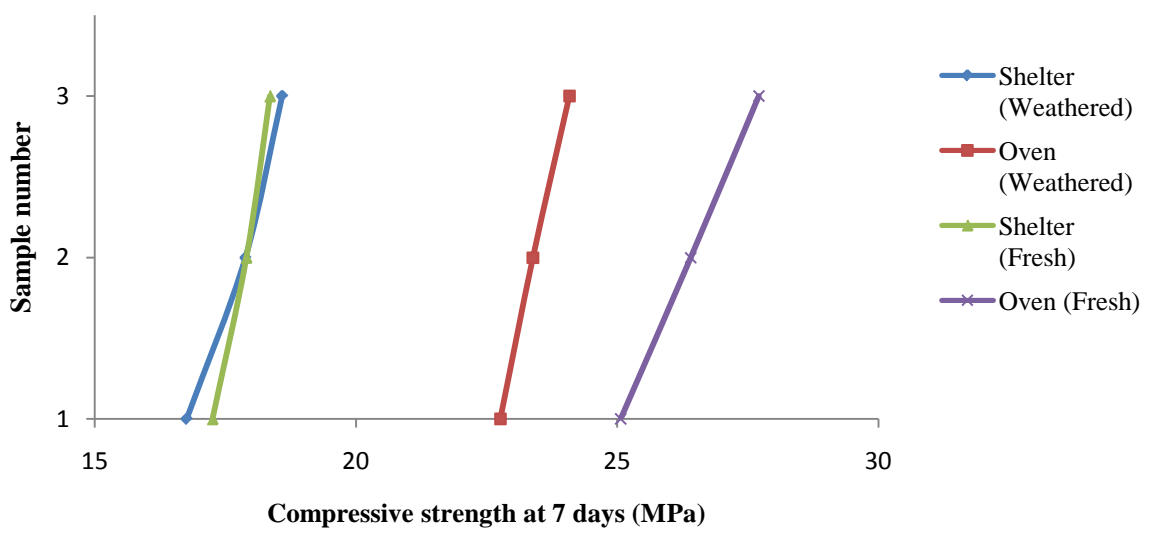

Figure 11. Effect of the drying method on tailings strength after stabilization.

When comparing the fresh and weathered tailings it shall be taken into account the fact that preparation conditions are not totally identic. Indeed, the optimums applied during the preparation of weathered and fresh tailings are different for some parameters. For example the optimal percentages by mass of $\mathrm{NaOH}$ solution are $18 \%$ and $21 \%$ respectively for fresh and weathered tailings. This slight difference in the behaviour of fresh and weathered tailings could be explained by their mineralogical composition. The weathered tailings contain more secondary clay minerals, kaolinite particularly, which have a higher potential of water absorption [17].

The alkalinity plays a key role in the geopolymerization amount of reactions. Indeed, the crystalline structure of the material is more easily broken to enable the formation of new amorphous compounds by forming bonds between silicon, aluminium, sodium and oxygen [1] [2]. For the Sabodala tailings, the amount of amorphous gel formed during the stabilization seems to be intimately dependent on the alkalinity created by the sodium hydroxide solution. In addition, a more concentrated solution brings more $\mathrm{Na}$ cations to feed the amorphous compounds.

The addition of cement is contributing to improving the compactness of the stabilized tailings by forming cementitious material filling the voids and reducing then the porosity. This leads to improvement of mechanical properties. However, at the same time, the cement consumes the water of the alkaline solution for its hydration causing therefore a modification of the tailings/solution ratio. The percentage by mass of the alkaline solution is then moved from its optimum resulting in a decrease of tensile and compressive strength. The lime has the same contribution than the cement but differ from it by the amount of cimentitious material formed. This explains why the lime gives better strength than cement.

There is an optimal percentage by mass of solution to be mixed with the tailings to have the best strengths. Beyond this optimum, the porosity will tend to increase leading to the reduction of the strengths. An insufficient amount of solution does not enable enough contact between the solution and the surface of 
tailings' particles to produce the brake of the crystalline structure and the formation of the gel.

The temperature of curing has also a strong effect on the geopolymerization process. However, when the curing temperatures are too high, most of changes made will be reversible making the stabilized tailings having weak strengths after the process. That explained also why samples curing in the oven show a decrease of the mechanical properties after few weeks.

\section{Conclusions}

The preparation parameters impact considerably the compressive and tensile strength of the stabilized tailings.

Although strength increases with the increase of $\mathrm{NaOH}$ solution concentration, an 8 molar solution has been applied for other preparations given the economic aspects of sample treatment. The percentage by mass of cement is optimal at $3.5 \%$ and the one for sodium hydroxide solution, at $18 \%$ and $21 \%$ respectively for fresh and weathered tailings. The curing temperature is optimal at $210^{\circ} \mathrm{C}$ but needs however more investigation to understand the influence of the $\mathrm{NaOH}$ solution concentration on it. Ahmari and Zhang [1] have established curing temperature optimum of $90^{\circ} \mathrm{C}$ for stabilized copper mine tailings suggesting that this parameter is very sensitive to the initial raw material nature and preparation conditions.

Drying treated material in an oven results in better strength at 7 days than drying it under a shelter. However with samples dried in an oven, the strength decreases considerably with the time whereas they are maintained for a drying under a shelter. The addition of limes results also in higher strength than the usage of cement.

In general, the stabilized fresh tailings show slight better compressive and tensile strength than the weathered one and require less $\mathrm{NaOH}$ solution which is the most expensive product involved in the preparation.

\section{Acknowledgements}

This study was conducted at the Cheikh Anta Diop University of Dakar and with the support of Teranga Gold Corporation as part of its corporate social responsibility program.

\section{References}

[1] Palmero, P., Formia, A., Tulliani, J.-M. and Antonaci, P. (2017) Valorisation of Aluminosilicate Stone Muds: From Wastes to Source Materials for Innovative Alkali-Activated Materials. Cement and Concrete Composites, 83, 251-262. https://doi.org/10.1016/j.cemconcomp.2017.07.011

[2] Ahmari, S. and Zhang, L. (2011) Production of Eco-Friendly Bricks from Copper Mine Tailings through Géopolymérisation. Construction and Building Materials Journal, 29, 223-231.

[3] Diop, M.B., Grutzeck, M.W. and Molez, L. (2011) Comparing the Performances of 
Bricks Made with Natural Clay and Clay Activated by Calcination and Addition of Sodium Silicate. Journal of Applied Clay Sciences, 54, 172-178. https://doi.org/10.1016/j.clay.2011.08.005

[4] Peel, M.C., Finlayson, B.L. and McMahon, T.A. (2007) Updated World Map of the Köppen-Geiger Climate Classification. Hydrology and Earth System Sciences, 11, 1633-1644. https://doi.org/10.5194/hess-11-1633-2007

[5] Tropica Environmental Consultants (2006) Projet d'Exploitation d'Or, d'Argent et de Substances Connexes a Sabodala de SMC: Etude d'Impact Environnemental et Social. Tropica Environmental Consultants, 186 p.

[6] Hirdes, W. and Davis, D.W. (2002) U-Pb Geochronology of Paleoproterozoic Rocks in the Southern Part of the Kédougou-Kénieba Inlier, Senegal, West Africa: Evidence for Diachronous Accretionary Development of the Eburnean Province. Precambrian Research, 118, 83-99. https://doi.org/10.1016/S0301-9268(02)00080-3

[7] Rhys, D. (2010) Report on May 2010 Geological Work at the Sabodala Mine. Panterra Geoservices Inc, $35 \mathrm{p}$.

[8] AMC Consultants Canada (2010) Sabodala Gold Project, Senegal, West Africa; Technical Report for Teranga Gold Corporation. Teranga Gold Corporation, 148 p.

[9] NF P 94-056 (1996) Soil: Investigation and Testing-Granulometric Analysis-Dry Sieving Method after Washing. $15 \mathrm{p}$.

[10] NF P 94-057 (1992) Soil: Investigation and Testing-Granulometric Analysis-Hydrometer Method. $17 \mathrm{p}$.

[11] (2015) ALS Minerals Report $n^{\circ}$ ALSCR-15-07, 3.

[12] NF EN ISO 14688-1 (2003) Geotechnical Investigation and Testing-Identification and Classification of Soil-Part 1: Identification and Description. International Organization for Standardization, Geneva, $19 \mathrm{p}$.

[13] Bakharev, T. (2005) Geopolymeric Materials Prepared Using Class F Fly Ash and Elevated Temperature Curing. Cement and Concrete Research, 35, 1224-1232. https://doi.org/10.1016/j.cemconres.2004.06.031

[14] Jha, A.K. and Sivapullaiah, P.V. (2015) Mechanism of Improvement in the Strength and Volume Change Behavior of Lime Stabilized Soil. Journal of Engineering Geology, 198, 53-64. https://doi.org/10.1016/j.enggeo.2015.08.020

[15] Consoli, N.C., Nierwinski, H.P., Silva, A.P. and Sosnoski, J. (2017) Durability and Strength of Fiber-Reinforced Compacted Gold Tailings-Cement Blends. Journal of Geotextiles and Geomembranes, 45, 98-102. https://doi.org/10.1016/j.geotexmem.2017.01.001

[16] Kiventerä, J., Golek, L., Yliniemi, J., Ferreira, V., Deja, J. and Illikainen, M. (2016) Utilization of Sulphidic Tailings from Gold Mine as a Raw Material in Géopolymérisation. International Journal of Mineral Processing, 149, 104-110. https://doi.org/10.1016/j.minpro.2016.02.012

[17] Zhang, N., Liu, L., Hou, D., He, M. and Liu, Y. (2014) Geomechanical and Water Vapor Absorption Characteristics of Clay-Bearing Soft Rocks at Great Depth. International Journal of Mining Science and Technology, 24, 811-818. https://doi.org/10.1016/j.ijmst.2014.10.013 
Submit or recommend next manuscript to SCIRP and we will provide best service for you:

Accepting pre-submission inquiries through Email, Facebook, LinkedIn, Twitter, etc. A wide selection of journals (inclusive of 9 subjects, more than 200 journals)

Providing 24-hour high-quality service

User-friendly online submission system

Fair and swift peer-review system

Efficient typesetting and proofreading procedure

Display of the result of downloads and visits, as well as the number of cited articles Maximum dissemination of your research work

Submit your manuscript at: http://papersubmission.scirp.org/

Or contact gep@scirp.org 